University of Nebraska - Lincoln

DigitalCommons@University of Nebraska - Lincoln

2009

\title{
Studying Oil, Islam, and Women as if Political Institutions Mattered
}

Alice Kang

University of Nebraska - Lincoln, akang2@unl.edu

Follow this and additional works at: https://digitalcommons.unl.edu/poliscifacpub

Part of the Political Science Commons

Kang, Alice, "Studying Oil, Islam, and Women as if Political Institutions Mattered" (2009). Faculty Publications: Political Science. 42.

https://digitalcommons.unl.edu/poliscifacpub/42

This Article is brought to you for free and open access by the Political Science, Department of at DigitalCommons@University of Nebraska - Lincoln. It has been accepted for inclusion in Faculty Publications: Political Science by an authorized administrator of DigitalCommons@University of Nebraska - Lincoln. 


\section{Studying Oil, Islam, and Women as if Political Institutions Mattered \\ Alice Kang, University of Wisconsin, Madison \\ doi: $10.1017 / \mathrm{S} 1743923 \times 09990377$}

By asserting that oil, not Islam, hurts gender equality, Michael Ross (2008) has made an important contribution to the debate on whether Islam bodes ill for women (Fish 2002; Inglehart and Norris 2003; Spierings, Smits, and Verloo 2009). Ross suggests that oil production decreases the number of female workers in countries with occupational segregation. The more women are left out of the formal economy, the fewer opportunities and resources they have for becoming influential political constituencies. According to Ross, "[t]his leaves oil-producing states with atypically strong patriarchal cultures and political institutions" (p. 107). Employing the same set of countries and data used in Ross (2008), I show that the institution of gender quotas, which is omitted from his statistical analyses, offsets the effects of oil rents on women's political representation. Gender quotas increase women's representation in Muslim majority and non-Muslim majority countries and in countries that are oil rich and oil poor. ${ }^{1}$ That "petroleum perpetuates patriarchy" (p. 120) is a tendency, not destiny.

I thank Michael Ross for sharing his data and for responding to my questions. I thank Mark Copclovitch, Stéphane Lavertu, Kathleen Klaus, Aili Mari Tripp, and participants at the Comparative Rescarch Colloquium at the University of Wisconsin, Madison, for their comments.

1. I make a conscious decision to use the term "Muslim majority." In Muslim majority countries, more than 50\% of the population identify as Muslim. In Islamic countries, Islam is adopted as the state religion. 


\section{The Role of Political Institutions}

Ross recognizes that political institutions affect women's chances of taking office. $^{2}$ His models include measures of democracy, proportionalrepresentation electoral system, closed party lists, and district magnitude. To better capture the causal process by which women are elected, I suggest two modifications.

First, include quotas in models of political representation inasmuch as in-depth country and cross-national studies demonstrate that gender quotas have become a "fast track" for women seeking public office since 1995 (Bhavnani 2009; Dahlerup and Freidenvall 2005; Htun and Jones 2002; Jones 1998; Paxton, Hughes, and Painter n.d.; Tripp and Kang 2008). As of 2008, more than 100 countries around the world use voluntary political party and compulsory legal quotas. Out of 49 predominantly Muslim countries, 22 (44.9\%) have adopted quotas. Of 64 countries that produced more than $\$ 100$ in oil rents in a single year, $33(51.6 \%)$ have adopted quotas (see Table 1). Ross's model appears to obtain more accurate estimations by including quotas.

Second, consider how institutions and natural resources shape one another to better understand the conditions under which resources generate gendered effects. Political institutions may alter the incentive structure that encourages rent-seeking behavior in resource-abundant countries (Mehlum, Moene, and Torvik 2006; Robinson, Torvik, and Verdier 2006). In the absence of a quota system, leaders may be more likely to ignore the demands of the female electorate during an oil boom. When quotas are in place, leaders may cater more to women's demands even during an oil boom. In an authoritarian state, leaders may disregard women's demands when oil is plentiful, whereas leaders in a democratic state may seek out female voters by using oil revenues to provide jobs, education, and health care. A similar hypothesis can be made about the effects of electoral systems on the use of natural resources.

\section{Data and Results}

Replicating Ross's cross-sectional analysis, I examine whether political institutions offset the impact of oil on women's political representation. The dependent variable is Female Seats, the percentage of women in

2. In this essay, institutions are "rules and procedures (both formal and informal) that structure social interaction by constraining and enabling actors' behavior" (Helmke and Levitsky 2004, 727). 
Table 1. Gender quotas for lower house and unicameral seats in oil-rich countries, 1960-2008 (years where oil rents exceeded \$100 per capita)

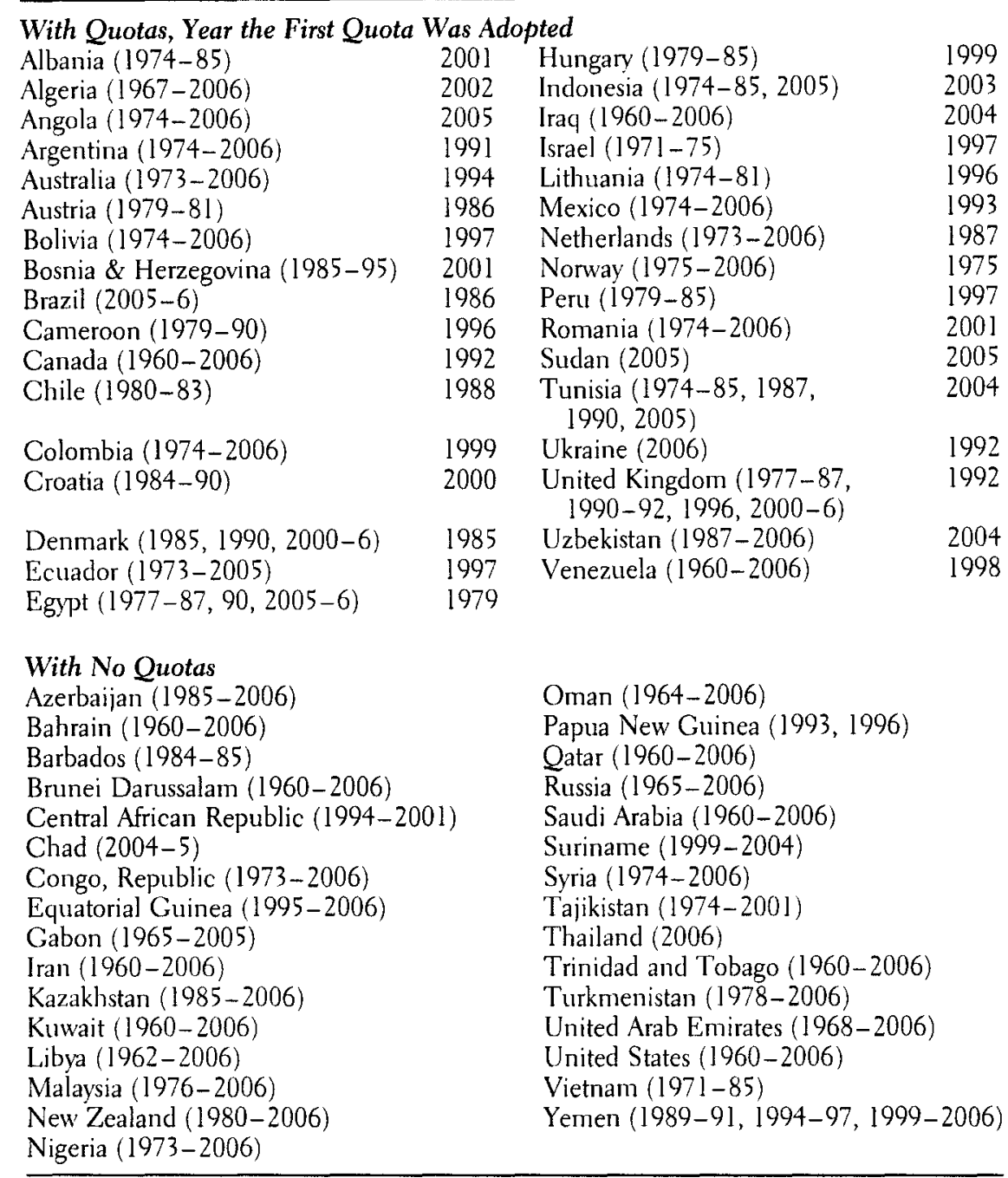

Note: Several countries dropped their quotas (c.g., Colombia, F.gypt). Years of quota adoption are from International IDEA (2009), Dahlerup (2006), and Krook (2009). Oil rent years are from Ross's longitudinal data set.

lower house and unicameral parliaments in 2002 or the most recent year for which the data are available. Ross's key independent variable is Oil Rents, the value of oil and gas production minus the extraction costs divided by the midyear population. Oil Rents and other economic 
variables are measured in constant 2000 dollars. I add Quotas, a dichotomous variable of whether voluntary party quotas or any legally mandated quotas were in effect for the election reported in Ross's data set. Information on quotas is compiled from the Global Database of Quotas for Women, Dahlerup (2006), and Krook (2009).

The percentage of women in parliament averages $15.7 \%$ in oil-poor countries, in contrast to $12.4 \%$ in oil-rich countries (Table 2 , replicating Ross's Table 3). I further disaggregate the sample by Quotas. Oil-rich countries with quotas have on average slightly higher rates of female representation than oil-poor countries with quotas, unless the sample is limited to countries not in the Organization for Economic Co-operation and Development (OECD). The descriptive statistics support Ross's idea that oil's impact in developing countries differs from that of OECD countries. Oil-producing countries seem less friendly to women given that $27.0 \%$ of oil-rich countries, while half of oil-poor countries have quotas. Nevertheless, the descriptive statistics indicate that quotas should be included in models predicting rates of women's representation. Table 3 reestimates Ross's ordinary least squares (OLS) models (see his Table 4). The presence of quotas is positively and significantly correlated with women's representation when controlling for oil rents, female labor force participation (model 6) and political institutions like democracy and electoral system (model 7). The findings are robust to various model specifications (including region dummies, excluding the two most influential cases) with the exception of a model that includes a control variable for closed lists electoral systems, which had a smaller sample of

Table 2. Parliamentary seats held by women, 2002 (percentage)

\begin{tabular}{|c|c|c|c|c|c|c|}
\hline & \multicolumn{3}{|c|}{ Oil Rich } & \multicolumn{3}{|c|}{ Oil Poor } \\
\hline & $\begin{array}{c}\text { No Quota } \\
(n=27)\end{array}$ & $\underset{(n=10)}{Q u o t a}$ & $\begin{array}{c}\text { All } \\
(n=37)\end{array}$ & $\begin{array}{c}\text { No Quota } \\
(n=63)\end{array}$ & $\begin{array}{c}\text { Quota } \\
(n=63)\end{array}$ & $\begin{array}{c}\text { All } \\
(n=126)\end{array}$ \\
\hline $\begin{array}{l}\text { Muslim } \\
\text { majority }\end{array}$ & 4.1 & 13.5 & 5.8 & 8.5 & 12.9 & 10.6 \\
\hline $\begin{array}{l}\text { Non-Muslim } \\
\text { majority }\end{array}$ & 15.4 & 21.5 & 17.4 & 13.5 & 19.8 & 16.6 \\
\hline $\begin{array}{l}\text { Non-Muslim } \\
\text { majority } \\
\text { (non- } \\
\text { OECD) }\end{array}$ & 12.3 & 16.1 & 13.1 & 13.0 & 17.3 & 15.0 \\
\hline All & 10.0 & 19.1 & 12.4 & 12.7 & 18.8 & 15.7 \\
\hline
\end{tabular}

Note: Oil-rich countries generate at least $\$ 100$ per capita in oil rents. 
Table 3. Cross-sectional OLS regressions on female seats in parliament

\begin{tabular}{|c|c|c|c|c|c|c|c|}
\hline & $\begin{array}{c}\text { Ross Model } 4 \\
\text { (I) }\end{array}$ & $\begin{array}{l}\text { Modified } 4 \\
\text { (2) }\end{array}$ & $\begin{array}{c}\text { Ross Model } 5 \\
\text { (3) }\end{array}$ & $\begin{array}{l}\text { Modified } 5 \\
\text { (4) }\end{array}$ & $\begin{array}{c}\text { Ross Model } 7 \\
\text { (5) }\end{array}$ & $\begin{array}{l}\text { Modified } 7 \\
\text { (6) }\end{array}$ & $\begin{array}{c}\text { Interaction } \\
\text { Term (7) }\end{array}$ \\
\hline Income $(\log )$ & $\begin{array}{l}0.320^{* * *} \\
(3.41)\end{array}$ & $\begin{array}{l}0.276^{* *} \\
(2.98)\end{array}$ & $\begin{array}{l}0.329^{* * *} \\
(3.74)\end{array}$ & $\begin{array}{l}0.284^{* * *} \\
(3.27)\end{array}$ & $\begin{array}{l}0.367^{* * *} \\
(4.13)\end{array}$ & $\begin{array}{l}0.351^{* * *} \\
(4.06)\end{array}$ & $\begin{array}{l}0.311^{* * * *} \\
(3.73)\end{array}$ \\
\hline Middle East & $\begin{array}{c}-0.193^{*} \\
(2.42)\end{array}$ & $\begin{array}{l}-0.188^{* *} \\
(2.72)\end{array}$ & $\begin{array}{c}-0.08 \\
(0.84)\end{array}$ & $\begin{array}{r}-0.065 \\
(0.77)\end{array}$ & $\begin{array}{l}-0.253^{*} \\
(3.28)\end{array}$ & $\begin{array}{l}-0.258^{* * *} \\
(3.74)\end{array}$ & $\begin{array}{l}-0.267^{* *} \\
(5.15)\end{array}$ \\
\hline Islam & $\begin{array}{c}-0.139 \\
(1.56)\end{array}$ & $\begin{array}{r}-0.132 \\
(1.63)\end{array}$ & $\begin{array}{r}-0.103 \\
(1.17)\end{array}$ & $\begin{array}{r}-0.095 \\
(1.22)\end{array}$ & $\begin{array}{r}-0.144 \\
(1.50)\end{array}$ & $\begin{array}{c}-0.156 \\
(1.81)\end{array}$ & \\
\hline Oil rents & $\begin{array}{l}-0.218^{* \ldots} \\
(3.32)\end{array}$ & $\begin{array}{l}-0.167^{* *} \\
(2.86)\end{array}$ & $\begin{array}{c}-0.152^{*} \\
(2.16)\end{array}$ & $\begin{array}{r}-0.104 \\
(1.65)\end{array}$ & $\begin{array}{l}-0.238^{* *} \\
(3.46)\end{array}$ & $\begin{array}{l}-0.207^{* *} \\
(3.21)\end{array}$ & $\begin{array}{r}-0.014 \\
(0.04)\end{array}$ \\
\hline Polity & & & & & $\begin{array}{c}-0.298^{*} \\
(2.94)\end{array}$ & $\begin{array}{c}-0.322^{\text {* } 3 x} \\
(3.18)\end{array}$ & \\
\hline $\begin{array}{l}\text { Proportional } \\
\text { representation }\end{array}$ & & & & & $0.316^{\frac{12}{4}}$ & $0.265^{* * *}$ & \\
\hline Female LFP & & & $\begin{array}{l}0.309^{* \star * *} \\
(3.68)\end{array}$ & $\begin{array}{l}0.314^{* * * *} \\
(3.95)\end{array}$ & $(4.30)$ & $(3.86)$ & \\
\hline Quotas & & $\begin{array}{l}0.261^{* * * *} \\
(3.58)\end{array}$ & & $\begin{array}{l}0.263^{* * *} \\
(3.77)\end{array}$ & & $\begin{array}{l}0.238^{* * * *} \\
(3.49)\end{array}$ & $\begin{array}{l}0.300^{* *} \\
(2.86)\end{array}$ \\
\hline Oil $^{\star}$ Quotas & & & & & & & $\begin{array}{r}0.192 \\
(0.50)\end{array}$ \\
\hline Observations & 161 & 161 & 160 & 160 & 161 & 161 & 161 \\
\hline R-squared & 0.26 & 0.33 & 0.33 & 0.39 & 0.35 & 0.40 & 0.32 \\
\hline
\end{tabular}


88 countries. In a reduced-form simulation using Clarify 2.0, where the value of income is set at the mean and the country is not in the Middle East, the percentage of women in parliament in the absence of oil and absence of quotas is $14 \%$. If quotas are introduced, the percentage increases to $19.1 \%$ (an increase of $36 \%$ ). If there are no quotas and the amount of oil rents is $\$ 1,280$ (about a one standard deviation rise from 0 ), the percentage of women in parliament decreases from $14 \%$ to $12.1 \%$.

To assess whether institutions mitigate the impact of oil, I include an interaction term (Oil Rents $\times$ Quotas) in a baseline model that includes controls for income and the Middle East region (model 7). The standard results table, however, does not provide much useful information when using multiplicative interaction models. In particular, the insignificance of the interaction term does not imply the absence of meaningful intervening effects (Brambor, Clark, and Golder 2006, p. 74). To assess whether the marginal effect of oil rents differs between quota and nonquota-holding countries, it is necessary to go an extra step. Figure 1

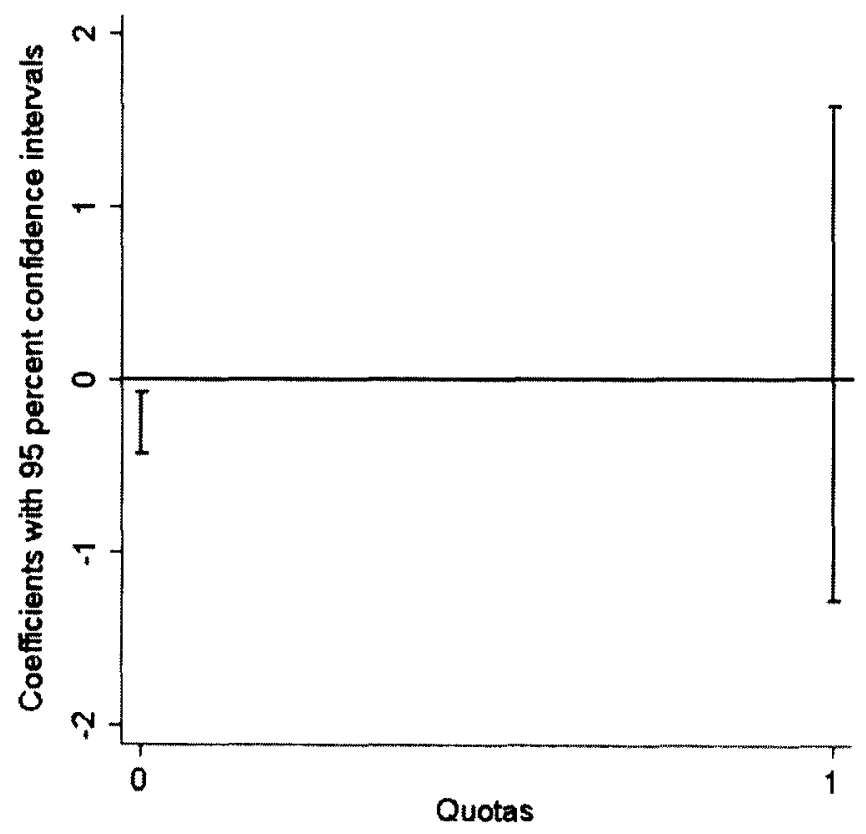

Figurk 1. Coefficients relating oil rents to women's political representation, at different levels of quotas (base model). (Figure assembled with coding from Braumoeller 2004.) 
illustrates how the coefficients and confidence intervals on oil rents vary across different levels of quotas. In the absence of quotas, the effect of oil rents on women's representation is significantly negative, supporting Ross's claim that oil reduces women's representation. In the presence of quotas, the effect of oil rents on women's representation is not statistically significant as zero falls within the $95 \%$ confidence interval, which calls for further investigation into the role of institutions.

\section{Conclusion}

In this essay, I have argued that scholars should also consider how political institutions affect the resource curse on women. Four pressing questions emerge:

1. What is the effect of oil on women's mobilization and movement success? Does oil production make it more difficult for women in parliament to influence politics?

2. What are the causal mechanisms by which political institutions mitigate the perverse effects of oil? Do institutions alter the economic aspects of the gendered resource curse (i.e., Dutch disease) or do institutions lessen the resource curse by changing the incentives that rent-seeking leaders face?

3. To what extent are institutions endogenous to natural resources? Why do some oil-producing countries adopt gender quotas while others do not? Quota adoption may not be endogenous to previous levels of female representation (Paxton, Hughes, and Painter, n.d.). Yet Table 2 indicates that quotas may be endogenous to oil production.

4. Do institutions also constrain the ways in which religion influences political outcomes for women? 'This replication corroborates Ross's claim that Islam, measured by the proportion of the population that are Muslim, does not correlate with lower rates of women's representation. Nuanced analyses suggest that the distribution of resources influences the strength of organized religion (Blofield 2006), as does the relationship between state and societal leaders (Charrad 2001; Htun 2003).

Ross's study will inspire scholars to pay more attention to the gendered dimensions of the resource curse. This essay finds, however, that gender quotas may offset the negative effect of oil rents on the presence of women in national parliaments. The widespread adoption of gender quotas has increased women's parliamentary representation in Muslim majority and non-Muslim majority countries and in oil-rich and oil-poor countries. Our understanding of the factors that help improve women's 
lives will grow, so long as we consider how political institutions mitigate or exacerbate - the pernicious effect of natural resources on women.

\section{REFERENCES}

Bhavnani, Rikhil. 2009. "Do Electoral Quotas Work after They Are Withdrawn? Evidence from a Natural Experiment in India." American Political Science Review 103 (1):23-35.

Blofield, Merike. 2006. The Politics of Moral Sin: Abortion and Divorce in Spain, Chile and Argentina. New York: Routledge.

Brambor, Thomas, William Roberts Clark, and Matt Golder. 2006. "Understanding Interaction Models: Improving Empirical Analysis." Political Analysis 14 (1): 63-82.

Braumoeller, Bear. 2004. "Interaction Term Checklist for Authors With Annotated Stata Batch File for Graphing Interaction Effects." http://polisci.osu.edu/faculty/ braumoeller/custom/checklist.html (May 30, 2009).

Charrad, Mounira. 2001. States and Women's Rights: The Making of Postcolonial Tunisia, Algeria, and Morocco. Berkeley and Los Angeles; University of California Press.

Dahlerup Drude, ed. 2006. Women, Quotas, and Politics. New York: Routledge.

Dahlerup, Drude, and Lenita Freidenvall. 2005. "Quotas as a 'Fast Track' to Equal Representation for Women: Why Scandinavia is No Longer the Model." International Feminist Journal of Politics 7 (1): 26-48.

Fish, Steven. 2002. "Islam and Authoritarianism." World Politics 55 (1): 4-37.

Helmke, Gretchen, and Steven Levitsky. 2004. "Informal Institutions and Comparative Politics: A Research Agenda." Perspectives on Politics 2 (4): 725-40.

Htun, Mala. 2003. Sex and the State: Abortion, Divorce, and the Family Under Latin American Dictatorships and Democracies. Cambridge: Cambridge University Press.

Htun, Mala, and Mark Jones. 2002. "Engendering the Right to Participate in DecisionMaking: Electoral Quotas and Women's Leadership in Latin America." In Gender and the Politics of Rights and Democracy in Latin America, ed. Nikki Craske, and Maxine Molyneux. New York: Palgrave.

Inglehart, Ronald, and Pippa Norris. 2003. Rising Tide: Gender Equality and Cultural Change Around the World. Cambridge: Cambridge University Press.

International IDEA. 2009. "Global Database of Quotas for Women." http://www. quotaproject.org/index.cfm (April 29, 2009).

Jones, Mark. 1998. "Gender Quotas, Electoral Laws, and the Election of Women: Lessons from the Argentine Provinces." Comparative Political Studies 31 (1): 3-21.

Krook, Mona Lena. 2009. Quotas for Women in Politics: Gender and Candidate Selection Reform Worldwide. Oxford: Oxford University Press.

Mehlum, Halvor, Karl Moene, and Ragnar Torvik. 2006. "Institutions and the Resource Curse." Economic Joumal $116(508): 1-20$.

Paxton, Pamela, Melanie Hughes, and Matthew Painter. N.d. "Growth in Women's Political Representation: A Longitudinal Exploration of Democracy, Electoral System, and Gender Quotas." European Journal of Political Research. Forthcoming.

Robinson, James, Ragnar Torvik, and Thierry Verdier. 2006. "Political Foundations of the Resource Curse." Journal of Development Economics 79 (2): 447-68.

Ross, Michael. 2008. "Oil, Islam, and Women." American Political Science Review 102 (1): $107-23$.

Spierings, Niels, Jeroen Smits, and Mieke Verloo. 2009. "On the Compatibility of Islam and Gender Equality: Effects of Modernization, State Islamization, and Democracy on Women's Labor Market Participation in 45 Muslim Countries." Social Indicators Research 90 (3): $503-22$. 
Tripp, Aili Mari, and Alice Kang. 2008. "The Global Impact of Quotas: On the Fast Track to Increased Female Legislative Representation." Comparative Political Studies 41 (3): $338-61$. 